\title{
White spruce establishment in two boreal Ontario mixedwoods: 13-year results
}

\author{
by R.F. Sutton ${ }^{1}$ and T.P. Weldon ${ }^{2}$
}

An experiment to investigate techniques for establishing white spruce (Picea glauca [Moench] Voss) in boreal Ontario mixedwood was begun in 1985 in Oates Twp. Eight 25-tree plots were established in each of nine treatments: three mechanical site preparation treatments (none, disk- trenching, and toothed-blading) in combination with three kinds of chemical weed control (none, Velpar $\mathrm{L}^{\circledR}$ at the time of planting, and Vision ${ }^{\circledR}$ during the second growing season). The experiment was repeated the following year in the adjacent township of Oswald. The mechanical treatments were applied as planned, but the herbicide treatments deviated somewhat from the plan. Fifth-year results were reported in this journal in 1995. In the eighth growing season, a ground-spray release treatment with Vision ${ }^{\circledR}$ was applied to four randomly selected 25 -tree plots in each original treatment. Performance of white spruce after 13 growing seasons was significantly influenced by site preparation: survival averaged 65 and $79 \%$ without release in the blading and trenching treatments, respectively, and $22 \%$ in the untreated control; with release, survival averaged 74 and $80 \%$ in the blading and trenching treatments, respectively, and $24 \%$ in the untreated control. Growth was greatest in the bladed treatment, poorest by far in the untreated control. The ineffectiveness of herbicides in these experiments is surprising in view of successes elsewhere. The modest response to release was significant for $13^{\text {th }}$-year increment.

Key words: site preparation, toothed blading, trenching, release

Une étude pour évaluer les techniques d'établissement de l'épinette blanche (Picea glauca [Moench] Voss) dans les forêts mélangées du nord de l'Ontario a débuté en 1985 dans le canton d'Oates. Huit parcelles de 25 arbres ont été établies dans chacun des neuf traitements : trois traitements mécaniques de préparation du terrain (pas de traitement, scarifiage par sillons et coupe à la cisaille dentée) combinés avec trois traitements chimiques de contrôle de la végétation indésirable (aucun traitement, Velpar L ${ }^{\circledR}$ au moment de la plantation, et Vision ${ }^{\circledR}$ au cours de la deuxième saison de croissance. L'étude a été répétée l'année suivante dans le canton adjacent d'Oswald. Les traitements mécaniques ont été réalisés tel que prévu, mais les traitements de phytocides ont quelque peu déviés du plan. Les résultats après cinq ans ont été présentés dans cette revue en 1995. Au cours de huitième année de croissance, un traitement de dégagement par pulvérisation terrestre de Vision ${ }^{\circledR}$ a été réalisé dans quatre parcelles de 25 arbres choisies au hasard dans chacun des traitements originaux. La performance de l'épinette blanche après 13 années de croissance a été significativement influencée par la préparation du terrain: le taux de survie était en moyenne de 65 et de $79 \%$ sans dégagement dans les traitements à la cisaille et de scarifiage par sillon, respectivement, et de $22 \%$ pour le témoin sans traitement; avec dégagement, le taux de survie était en moyenne de 74 et de $80 \%$ dans les traitements à la cisaille et de scarifiage par sillon, respectivement, et de $24 \%$ dans le témoin sans traitement. La croissance a été la plus importante pour le traitement par cisaille, et de loin la plus faible dans les parcelles témoins sans traitement. L'inefficacité des phytocides dans ces essais est surprenante lorsqu'on considère les succès obtenus ailleurs. La réponse modeste au dégagement a été significative pour l'accroissement de la treizième année.

Mots-clés: préparation du terrain, scarifiage par cisaille dentée, scarifiage par sillon, dégagement

\section{Introduction}

Further to the five-year results reported by Sutton and Weldon (1995), we now present 13-year results from a trial of nine silvicultural treatments for establishing white spruce (Picea glau$c a$ [Moench] Voss) in two boreal Ontario mixedwoods. White spruce were planted in Oates Township $\left(48^{\circ} 20^{\prime} \mathrm{N} ; 82^{\circ} 28^{\prime} \mathrm{W}\right)$ in 1985 in a randomized block design with eight replications of nine treatments. The same design but with separate randomization was used in the adjacent Oswald Township $\left(48^{\circ} 23^{\prime} \mathrm{N} ; 82^{\circ} 20^{\prime} \mathrm{W}\right)$ in 1986 . The mechanical treatments (none, disk- trenching, and toothed-blading) had been applied as planned, but the intended combination of the mechanical treatments with three kinds of chemical weed control (none, Velpar $\mathrm{L}^{\circledR}$ at the time of planting, and Vision ${ }^{\circledR}$ during the second growing season) was imperfectly achieved: the Velpar ${ }^{\circledR}$ treatment at Oates differed from that at Oswald, and the Vision ${ }^{\circledR}$ treatment at Oswald may have been omitted. These establishment

\footnotetext{
${ }^{1}$ Scientist Emeritus, Great Lakes Forestry Centre, 1219 Queen St. E., Sault Ste. Marie, ON P6A 2E5. E-mail: Sutton@nrcan.gc.ca

${ }^{2}$ Great Lakes Forestry Centre, 1219 Queen St. E., Sault Ste. Marie, ON P6A 2E5.
}

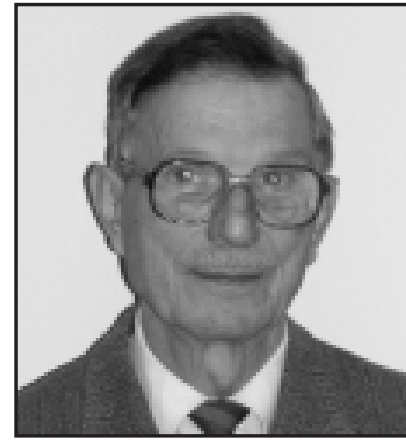

R.F. Sutton

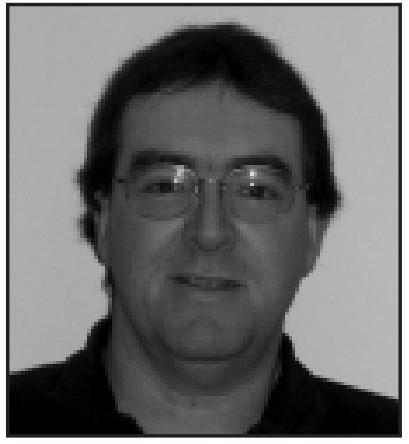

T.P. Weldon treatments are termed "original" herein to distinguish them from the subsequent release treatment. Fifth-year survival and growth of the spruce were clearly adequate after mechanical site preparation. Conclusions about the herbicide factor were not warranted because of the aberrations in application.

\section{Materials and Methods}

Methods through year 5 were described by Sutton and Weldon (1995). 
Table 1. Overview of 13-year performance of white spruce at Oswald and Oates, all treatments overall. SE Means in parentheses

\begin{tabular}{lrr}
\hline Variable & Oates & Oswald \\
\hline Survival $(\%)$ & 57 & 52 \\
Mean total height $(\mathrm{cm})$ & $252(3.3)$ & $174(3.8)$ \\
Mean current-year height increment $(\mathrm{cm})$ & $32(0.6)$ & $13(0.4)$ \\
Mean ground-level stem diameter $(\mathrm{mm})$ & $48(0.7)$ & $31(0.7)$ \\
\hline
\end{tabular}

\section{Eighth-year release treatment}

On 1-2 September 1992 at Oates, an operational release treatment using backpack sprayers applied a total of $21.25 \mathrm{~L}$ of Vision ${ }^{\circledR}$ to about $9 \mathrm{ha}(0.84 \mathrm{~kg}$ isopropylamine salt/ha overall) in ideal conditions (wind speed 0-3 kph, excepting one brief spell of 3-6 kph, and $14-18^{\circ} \mathrm{C}$ air temperature). Treated vegetation was sprayed to drip point. Four of the eight plots in each treatment, chosen at random, were clearly flagged, and excluded from the spraying. The release treatment at Oswald was carried out in 1993, also in the eighth growing season after planting.

\section{Thirteenth-year assessment}

Assessment of white spruce performance after 13 growing seasons (at Oates in 1997 and Oswald in 1998) provides data by which to determine (a) the 13-year response of white spruce to the original treatments, and (b) the effect after five years of the eighth-year release treatment. Total height, current annual height increment, and ground-level stem diameter were determined for each surviving spruce in all the original plots. Each tree was also subjectively allocated a condition index ( $1=$ good form, good vigor; 2 = form less than ideal, vigor at least moderate; $3=$ poor form and/or vigor, long-term survival questionable, $4=$ tree dead or moribund).

\section{Statistical treatment}

As so often happens with silvicultural field experiments, the performance data from white spruce at Oates and Oswald are statistically flawed, in large part in consequence of the high mortality of white spruce in treatments without mechanical site preparation. Chi-square tests of mortality using actual numbers of trees were carried out for all treatments. However, analyses of growth are presented only for the six mechanical site preparation treatments in which $13^{\text {th }}$-year survival exceeded $50 \%$. The statistical analyses, including general linear ANOVA and Tukey pairwise comparisons, were carried out using Minitab 13 (2002) software. White spruce performance differed strongly between Oates and Oswald (Table 1); the two experiments are presented separately.

\section{Results}

\section{Survival of spruce at Oates}

Differences in survival among treatments (Table 2) were highly significant $\left(\mathrm{DF}=8, \chi^{2}=284, \mathrm{P}<0.001\right)$ as were differences among treatments grouped by site preparation method (DF $=$ $2, \chi^{2}=254, \mathrm{P}<0.001$ for non-release, and $\mathrm{DF}=2, \chi^{2}=279$, $\mathrm{P}<0.001$ for release treatments). Overall $13^{\text {th }}$-year survival rates for grouped site preparation treatments were: Trenched 69.7\%; Bladed 79.7\%; and Untreated 22.8\%. Several plots in treatments 7,8 , and 9 , which were not mechanically site prepared, lacked live sample trees after 13 years.

\section{Growth of spruce at Oates after 13 growing seasons}

Accordingly, growth data from treatments 7 through 9 were excluded from ANOVA. The original treatments at Oates significantly influenced $13^{\text {th }}$-year total height of white spruce $(\mathrm{P}=0.001)$ as well as height increment $(\mathrm{P}=0.001)$, and ground-level stem diameter $(\mathrm{P}=0.002)$ (Table 3$)$. The release treatment significantly $(\mathrm{P}=0.01)$ increased $13^{\text {th }}$-year height increment and ground-level stem diameter $(\mathrm{P}=0.016)$, but although $13^{\text {th }}$-year height increment in all of the original site preparation treatments was greater with than without release, in no instance was the difference significant $(\mathrm{P}=0.05)$ by pairwise comparison (Table 4). At the end of the $13^{\text {th }}$ growing season, trees were generally in poorer condition (i.e., with a higher average condition index) in the untreated portion of treatments than in the released portion, but the difference was not significant by either ANOVA or pairwise comparison. Ground-level stem diameter was similar to condition in this regard.

\section{Survival of spruce at Oswald}

Differences in survival among treatments (Table 5) were highly significant $\left(\mathrm{DF}=8, \chi^{2}=286, \mathrm{P}<0.001\right)$ as were differences among treatments grouped by site preparation method (DF $=$ $2, \chi^{2}=210, \mathrm{P}<0.001$ for non-release, and $\mathrm{DF}=2, \chi^{2}=118$, $\mathrm{P}<0.001$ for release treatments). Overall $13^{\text {th }}$-year survival rates for grouped site preparation treatments were: Trenched 62.0\%; Bladed 76.3\%; and Untreated 18.7\%. As at Oates, several plots without mechanical site preparation (treatments 7, 8, and 9) had no living sample trees after 13 years.

\section{Growth of spruce at Oswald after 13 growing seasons}

Growth data for white spruce in the trenched and bladed site preparation treatments at Oswald were examined by General Linear Model ANOVA (Minitab 13) (Table 6), as at Oates. Pairwise comparisons revealed consistent significant differences in white spruce growth between Trenched and Bladed treatments but no NR vs R pair was significant (Table 7).

\section{Discussion \\ Spruce survival at Oates}

Planting without mechanical site preparation at Oates gave only $23 \%$ survival after 13 growing seasons, whereas survival levels were mostly in the 70-90\% range after mechanical site preparation. Uncontrolled pre-established vegetation was a pow-

Table 2. Survival (\%) of white spruce at Oates 13 years after planting, by original treatment, with and without release; VE $=$ Velpar ${ }^{\circledR}, \mathrm{VI}=\mathrm{Vision}{ }^{\circledR}$

\begin{tabular}{|c|c|c|c|c|c|c|c|c|c|}
\hline Treatment no ${ }^{1}$. & 1 & 2 & 3 & 4 & 5 & 6 & 7 & 8 & 9 \\
\hline Mech site prep & \multicolumn{2}{|c|}{ Trenched } & & \multicolumn{2}{|c|}{ Bladed } & \multicolumn{4}{|c|}{ Untreated } \\
\hline Herbicide & - & VE & VI & - & VE & VI & - & VE & VI \\
\hline No release $^{2}$ & 71 & 55 & 70 & 66 & 81 & 90 & 5 & 38 & 23 \\
\hline Release & 74 & 64 & 84 & 69 & 85 & 87 & 14 & 41 & 16 \\
\hline
\end{tabular}

${ }^{1}$ Survival rates for Mechanical site preparation treatments (74.5\% overall) and Untreated control (23.0\% overall) differ too greatly to warrant statistical affirmation.

${ }^{2}$ Survival rates between No release and Release differed non-significantly overall, $\chi^{2}=2.68, \mathrm{P}>0.10$. 
Table 3. General linear model ANOVA, $13^{\text {th }}$-year total height, condition, annual height increment, and ground-level stem diameter of white spruce at Oates; adjusted SS used for tests

\begin{tabular}{|c|c|c|c|c|}
\hline Factor & DF & MS & $\mathbf{F}$ & $\mathbf{P}$ \\
\hline \multicolumn{5}{|l|}{ Total height } \\
\hline Original treatment & 5 & 11998 & 5.17 & 0.001 \\
\hline Release & 1 & 8046 & 3.47 & 0.071 \\
\hline Interaction & 5 & 1398 & 0.60 & 0.698 \\
\hline Error & 34 & 2321 & & \\
\hline Total & 45 & & & \\
\hline \multicolumn{5}{|l|}{ Condition } \\
\hline Original treatment & 5 & 0.6877 & 2.34 & 0.062 \\
\hline Release & 1 & 0.8772 & 2.99 & 0.093 \\
\hline Interaction & 5 & 0.0865 & 0.29 & 0.913 \\
\hline Error & 34 & 0.2936 & & \\
\hline Total & 45 & & & \\
\hline \multicolumn{5}{|l|}{ Increment } \\
\hline Original treatment & 5 & 330.54 & 5.18 & 0.001 \\
\hline Release & 1 & 476.42 & 7.46 & 0.010 \\
\hline Interaction & 5 & 27.71 & 0.43 & 0.822 \\
\hline Error & 34 & 63.87 & & \\
\hline Total & 45 & & & \\
\hline \multicolumn{5}{|l|}{ Diameter } \\
\hline Original treatment & 5 & 480.44 & 4.90 & 0.002 \\
\hline Release & 1 & 630.74 & 6.44 & 0.016 \\
\hline Interaction & 5 & 31.41 & 0.32 & 0.897 \\
\hline Error & 34 & 98.00 & & \\
\hline Total & 45 & & & \\
\hline
\end{tabular}

erful constraint. Mechanical removal of competing vegetation enhanced spruce survival rates, but herbicide treatment alone (the original Velpar ${ }^{\circledR}$-only and Vision ${ }^{\circledR}$-only treatments) provided variable and generally insufficient amelioration, although survival rates in these herbicide-only treatments were substantially higher than those in the untreated control. The variation in survival rate is attributable in part to site variability and to the previously mentioned aberrations in applying the treatments. Elsewhere, white spruce has been very successfully established by herbicide treatment alone in highly competitive mixedwood conditions (Sutton 1986, 1995; Harper et al. 1997; Boateng et al. 2000), but the shrub layer at Oates was affected only slightly by the herbicide treatments, presumably because rates of application were insufficient to control vegetation of that density, vigour, and composition.

\section{Effect of release treatment on survival of spruce at Oates}

The $13^{\text {th }}$-year overall survival rate of white spruce in the released plots at Oates was higher than in the non-released plots by $6.9 \%$, but the difference was not significant by chi-square test. Evidently, the release treatment eight years after planting may have been too late to influence survival rates.

\section{Effect of original treatments on growth of spruce at Oates}

White spruce growth and survival rates varied greatly with original treatment at Oates, with blading clearly the most successful. As well as securing high survival rates of the spruce, this treatment also promoted the development of vigorous trees commonly more than $3 \mathrm{~m}$ in height and some taller than $4 \mathrm{~m}$ after 13 growing seasons, with $13^{\text {th }}$-year height increments approaching $0.5 \mathrm{~m}$.

Trenching site preparation, though less successful than blading, gave results significantly better than did the treatments not involving mechanical site preparation.

The effectiveness of the original treatments undoubtedly depends on the degree to which each treatment controlled competing vegetation. The fertile soil at Oates (and Oswald) supports a vigorous shrub layer of alders (Alnus crispa [Ait.] Pursh and A. rugosa [DuRoi] Spreng.), hazel (Corylus cornuta Marsh), mountain maple (Acer spicatum Lam.), and pin cherry (Prunus pensylvanica L. f.), with raspberry (Rubus idaeus L.) and various grasses and sedges wherever there is enough light. Scattered aspen (Populus tremuloides Michx.) suckers and seedlings and white birch (Betula papyrifera Marsh.) also occur, but the tall shrubs pose the strongest competition to the outplanted spruce, especially for light. The greater and longer-lasting control of competition provided by blading site preparation than given by the other treatments is unmistakable after 13 growing seasons even to a casual observer. The white spruce planted after blading site preparation treatment still had the important benefit of side shelter to ameliorate the severity of boreal spring frost to which young white spruce in fully exposed situations are very vulnerable (Sutton 1982, 1992).

Effect of release treatment on growth of spruce at Oates

Release has influenced white spruce growth much less than has the original treatment, at least when assessed five years after application of the release treatment. Interactions were not significant. A sluggish response to release includes modest gains in $13^{\text {th }}$-year height increment and ground-level stem diameter, but the data do not allow inferences to be drawn about whether the response has run its course or may be continuing or even accelerating. Nor can the data indicate what response an earlier release treatment might have obtained, but it is clear that a tree in poor condition will have difficulty at best in responding to ameliorated conditions.

Table 4. Summary of white spruce mean total height, $13^{\text {th }}$-year height increment, ground-level stem diameter, and condition (see text), at Oates after 13 growing seasons, by original site preparation treatment and subsequent release (R) or non-release (NR), SE Means in parentheses

\begin{tabular}{|c|c|c|c|c|c|c|c|c|}
\hline \multirow[b]{2}{*}{ Treatment } & \multicolumn{2}{|c|}{$\begin{array}{c}\text { Total } \\
\text { height }\end{array}$} & \multicolumn{2}{|c|}{$\begin{array}{l}\text { Height increment } \\
\text { in } 13^{\text {th }} \text { year }\end{array}$} & \multicolumn{2}{|c|}{ Diameter } & \multicolumn{2}{|c|}{ Condition } \\
\hline & $\begin{array}{l}\mathrm{NR} \\
(\mathrm{cm})\end{array}$ & $\begin{array}{c}\mathrm{R} \\
(\mathbf{c m})\end{array}$ & $\begin{array}{l}\text { NR } \\
(\mathbf{c m})\end{array}$ & $\begin{array}{c}R \\
(\mathbf{c m})\end{array}$ & $\begin{array}{c}\mathbf{N R} \\
(\mathbf{m m})\end{array}$ & $\begin{array}{c}\mathrm{R} \\
(\mathbf{m m})\end{array}$ & $\begin{array}{c}\text { NR } \\
\text { (see text) }\end{array}$ & $\begin{array}{c}\frac{R}{\text { (see text) }} \\
\text { (s) }\end{array}$ \\
\hline 1 Trenched only & $208(28.7) \mathrm{a}^{1}$ & $229(17.6) \mathrm{a}$ & $22(3.0) \mathrm{a}$ & $26(2.4) \mathrm{ab}$ & $36(3.7) \mathrm{a}$ & $44(3.0) \mathrm{a}$ & $2.3(0.3) \mathrm{a}$ & $2.2(0.2) \mathrm{a}$ \\
\hline 2 Trenched + Velpar ${ }^{\circledR}$ & $207(19.9) \mathrm{a}$ & $230(24.4) \mathrm{a}$ & $22(4.0) \mathrm{a}$ & $28(3.8) \mathrm{ab}$ & $36(4.0) \mathrm{a}$ & $42(4.8) \mathrm{a}$ & $2.4(0.5) \mathrm{a}$ & $2.9(0.4) \mathrm{a}$ \\
\hline 3 Trenched + Vision ${ }^{\circledR}$ & $221(21.3) \mathrm{a}$ & $256(25.6) \mathrm{a}$ & $35(3.3) \mathrm{ab}$ & $43(4.3) \mathrm{b}$ & $48(3.7) \mathrm{a}$ & $56(4.2) \mathrm{a}$ & $2.2(0.1) \mathrm{a}$ & $1.6(0.2) \mathrm{a}$ \\
\hline 4 Bladed only & $293(29.5) \mathrm{a}$ & $326(37.1) \mathrm{a}$ & $34(7.1) \mathrm{ab}$ & $40(5.5) \mathrm{ab}$ & $51(6.6) \mathrm{a}$ & $60(8.8) a$ & $1.6(0.1) \mathrm{a}$ & $1.4(0.2) \mathrm{a}$ \\
\hline 5 Bladed + Velpar ${ }^{\circledR}$ & $253(35.7) \mathrm{a}$ & $317(8.5) \mathrm{a}$ & $25(6.6) \mathrm{ab}$ & $38(3.6) \mathrm{ab}$ & $47(8.0) \mathrm{a}$ & $61(5.7) \mathrm{a}$ & $2.1(0.2) \mathrm{a}$ & $1.8(0.2) \mathrm{a}$ \\
\hline 6 Bladed + Vision ${ }^{\circledR}$ & $302(17.9) \mathrm{a}$ & $285(23.4) \mathrm{a}$ & $37(0.8) \mathrm{ab}$ & $39(3.1) \mathrm{ab}$ & $56(2.1) \mathrm{a}$ & $57(4.6) \mathrm{a}$ & $1.6(0.1) \mathrm{a}$ & $1.6(0.2) \mathrm{a}$ \\
\hline
\end{tabular}

${ }^{1}$ Within columns, and between NR-R pairs within performance variables, values not followed by the same letter differ significantly (P $\left.>0.05\right)$ by Tukey pairwise comparison test. 


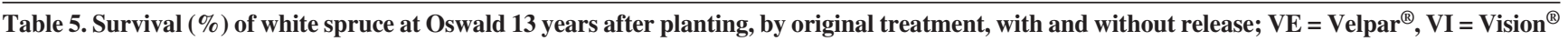

\begin{tabular}{|c|c|c|c|c|c|c|c|c|c|}
\hline Treatment no. ${ }^{1}$ & 1 & 2 & 3 & 4 & 5 & 6 & 7 & 8 & 9 \\
\hline Mech site prep & \multicolumn{2}{|c|}{ Trenched } & & \multicolumn{2}{|c|}{ Bladed } & \multicolumn{2}{|c|}{ Untreated } & & \\
\hline Herbicide & - & VE & VI & - & VE & VI & - & VE & VI \\
\hline No release $^{2}$ & 72 & 37 & 73 & 84 & 54 & 85 & 34 & 14 & 5 \\
\hline Release & 69 & 48 & 73 & 84 & 60 & 91 & 19 & 21 & 19 \\
\hline
\end{tabular}

${ }^{1}$ Survival rates for Mechanical site preparation treatments (69.2\% overall) and Untreated control (18.7\% overall) differ too greatly to warrant statistical affirmation.

${ }^{2}$ Survival rates between No release and Release differed non-significantly overall, $\chi^{2}=1.50, \mathrm{P}=0.30$.

\begin{tabular}{|c|c|c|c|c|}
\hline Factor & DF & MS & $\mathbf{F}$ & $\mathbf{P}$ \\
\hline \multicolumn{5}{|l|}{ Total height } \\
\hline Original treatment & 5 & 4668 & 32.83 & 0.000 \\
\hline Release & 1 & 243 & 0.17 & 0.682 \\
\hline Interaction & 5 & 976 & 0.69 & 0.637 \\
\hline Error & 36 & 1422 & & \\
\hline Total & 47 & & & \\
\hline \multicolumn{5}{|l|}{ Condition } \\
\hline Original treatment & 5 & 2.3649 & 16.47 & 0.000 \\
\hline Release & 1 & 0.5874 & 4.09 & 0.051 \\
\hline Interaction & 5 & 0.0146 & 0.10 & 0.991 \\
\hline Error & 36 & 0.1436 & & \\
\hline Total & 47 & & & \\
\hline \multicolumn{5}{|l|}{ Increment } \\
\hline Original treatment & 5 & 397.04 & 17.03 & 0.000 \\
\hline Release & 1 & 102.84 & 4.41 & 0.043 \\
\hline Interaction & 5 & 14.37 & 0.62 & 0.688 \\
\hline Error & 36 & 23.32 & & \\
\hline Total & 47 & & & \\
\hline \multicolumn{5}{|l|}{ Diameter } \\
\hline Original treatment & 5 & 1795.81 & 26.02 & 0.000 \\
\hline Release & 1 & 35.24 & 0.51 & 0.479 \\
\hline Interaction & 5 & 39.40 & 0.57 & 0.722 \\
\hline Error & 36 & 69.02 & & \\
\hline Total & 47 & & & \\
\hline
\end{tabular}

\section{Spruce survival at Oswald}

Survival rates varied significantly among the original treatments grouped by mode of mechanical site preparation $(\mathrm{DF}=$ $2, \chi^{2}=210, \mathrm{P}<0.001$ ) for original (non-release) treatments. Blading site preparation was clearly the most successful; without mechanical site preparation, survival in this experiment averaged only 19\% (Table 5). Mechanical site preparation treatments secured virtually the same survival rate whether or not Vision ${ }^{\circledR}$ was incorporated into the treatment, a circumstance suggesting the possibility that Vision ${ }^{\circledR}$ may not have been applied at Oswald at all. The significant depression of survival in the Velpar ${ }^{\circledR}$ treatments below those in the mechanical site preparation counterpart with or without Vision ${ }^{\circledR}$ has no ready explanation, and, in the absence of detailed records of the semioperational herbicide application, guessing of cause(s) is unhelpful. Nevertheless, hexazinone has elsewhere been strikingly successful in enabling young white spruce to become established even in competition with strong, well-established vegetation (Sutton 1986, 1995; Harper et al. 1997; Boateng et al. 2000). Much depends on the timing of herbicide application, and the rate must be appropriate to the kind (species and amount) of competition to be controlled. As well, some resid- ual vegetation is needed to provide side shade sufficient to ameliorate the late spring frosts that are so damaging to young white spruce in boreal climates (Sutton 1982).

Survival rates in the released plots of the originally untreated control were virtually identical whether or not $\operatorname{Velpar}^{\circledR}$ or Vision ${ }^{\circledR}$ had been applied in the original treatment, but in the unreleased plots survival was particularly low in the herbicideonly treatments. This compounds the difficulty of accounting for the ineffectiveness, or even possible harmfulness, of herbicide in these experiments.

\section{Effect of release treatment on survival of spruce at Oswald}

The $13^{\text {th }}$-year overall survival rate of white spruce in the released plots at Oswald was higher than in the non-released plots by $5.7 \%$. As at Oates, the effect of the release treatment on survival rate was suggestive, especially when considered along with the better condition of trees in the release treatments compared with non-released trees, but it was not statistically significant.

\section{Effect of original treatments on growth of spruce at Oswald}

At Oswald, as at Oates, the original treatments significantly $(\mathrm{P}<0.001)$ influenced $13^{\text {th }}$-year total height of white spruce, annual height increment, and ground-level stem diameter (Table 6).

White spruce outplanted at Oswald faced competition similar to that at Oates, and responded similarly to the original treatments, with performance positively related to the degree to which competition was relieved by treatment. The three blading site preparation treatments were clearly the most successful, producing vigorous trees commonly more than $3 \mathrm{~m}$ in height and some taller than $4 \mathrm{~m}$ after 13 growing seasons, and with $13^{\text {th }}$ year height increments approaching $0.5 \mathrm{~m}$, which reinforce the value of the high survival rates already mentioned.

Trenching site preparation, though obtaining significantly poorer performance $\left(13^{\text {th }}\right.$-year total height, annual increment, and ground-level stem diameter) than did blading, was significantly better than the treatments lacking mechanical site preparation.

\section{Effect of release treatment on growth of spruce at Oswald}

The release treatment significantly $(P=0.043)$ increased $13^{\text {th }}$ year height increment but not total height nor ground-level stem diameter. Just one pairwise comparison (NR vs R) was significant (Table 7); in treatment 6 (Blading + Vision ${ }^{\circledR}$ ), the condition of released trees was significantly better than those that had not been released and, in fact, significantly better than the trees in any other treatment, released or otherwise. As at Oates, the con- 
Table 7. Summary of white spruce mean total height, $13^{\text {th }}$-year height increment, ground-level stem diameter, and condition (see text), at Oswald after 13 growing seasons, by original site preparation treatment and subsequent release (R) or non-release (NR), SE Means in parentheses

\begin{tabular}{|c|c|c|c|c|c|c|c|c|}
\hline \multirow[b]{2}{*}{ Treatment } & \multicolumn{2}{|c|}{$\begin{array}{c}\text { Total } \\
\text { height }\end{array}$} & \multicolumn{2}{|c|}{$\begin{array}{l}\text { Height increment } \\
\text { in } 13^{\text {th }} \text { year }\end{array}$} & \multicolumn{2}{|c|}{ Diameter } & \multicolumn{2}{|c|}{ Condition } \\
\hline & $\begin{array}{c}\mathrm{NR} \\
(\mathrm{cm})\end{array}$ & $\begin{array}{c}\mathbf{R} \\
(\mathbf{c m})\end{array}$ & $\begin{array}{r}\mathrm{NR} \\
(\mathrm{cm})\end{array}$ & $\begin{array}{c}\mathbf{R} \\
(\mathbf{c m})\end{array}$ & $\begin{array}{c}\mathrm{NR} \\
(\mathrm{mm})\end{array}$ & $\begin{array}{c}\mathbf{R} \\
(\mathbf{m m})\end{array}$ & $\begin{array}{c}\text { NR } \\
\text { (see text) }\end{array}$ & $\begin{array}{c}\mathbf{R} \\
\text { (see text) }\end{array}$ \\
\hline 1 Trenched only & $110(11.7) \mathrm{a}^{1}$ & $124(20.2) \mathrm{a}$ & $6(0.4) \mathrm{a}$ & $10(3.6) \mathrm{a}$ & $19(1.9) \mathrm{a}$ & $20(2.3) \mathrm{a}$ & $3.1(0.1) \mathrm{a}$ & $2.8(0.3) \mathrm{a}$ \\
\hline 2 Trenched + Velpar ${ }^{\circledR}$ & $120(23.2) \mathrm{a}$ & $122(18.3) \mathrm{a}$ & $8(4.3) \mathrm{a}$ & $10(1.9) \mathrm{a}$ & $22(5.0) \mathrm{a}$ & $21(3.0) \mathrm{a}$ & $3.5(0.1) \mathrm{a}$ & $3.3(0.1) \mathrm{a}$ \\
\hline 3 Trenched + Vision ${ }^{\circledR}$ & $86(9.8) a$ & $104(11.9) \mathrm{a}$ & $3(0.2) \mathrm{a}$ & $6(0.9) \mathrm{a}$ & 14 (1.6)a & $18(2.4) \mathrm{a}$ & $3.2(0.0) \mathrm{a}$ & $3.1(0.0) \mathrm{a}$ \\
\hline 4 Bladed only & $251(15.8) \mathrm{b}$ & $233(31.0) \mathrm{b}$ & $19(2.3) \mathrm{b}$ & $21(2.6) \mathrm{b}$ & $45(4.3) \mathrm{b}$ & $45(7.4) b$ & $2.2(0.2) \mathrm{a}$ & $2.0(0.3) \mathrm{a}$ \\
\hline 5 Bladed + Velpar ${ }^{\circledR}$ & $266(12.6) \mathrm{b}$ & 244 (19.7)b & $21(2.0) \mathrm{b}$ & $21(1.7) \mathrm{b}$ & $49(3.5) \mathrm{b}$ & $45(5.7) \mathrm{b}$ & $2.8(0.2) \mathrm{a}$ & $2.7(0.2) \mathrm{a}$ \\
\hline 6 Bladed + Vision ${ }^{\circledR}$ & $234(22.1) \mathrm{b}$ & $269(19.1) \mathrm{b}$ & $15(2.3) \mathrm{b}$ & $22(3.1) b$ & $41(4.4) b$ & $50(4.5) \mathrm{b}$ & $2.2(0.3) \mathrm{a}$ & $1.9(0.1) \mathrm{b}$ \\
\hline
\end{tabular}

${ }^{1}$ Within columns, and between NR-R pairs within performance variables, values not followed by the same letter differ significantly (P $\left.>0.01\right)$ by Tukey pairwise comparison test.

dition of trees in the untreated portion of treatments was generally poorer than their released counterparts, but the difference was not significant by either ANOVA or pairwise comparison, other than the exception noted.

Without mechanical site preparation (the untreated, Velpar ${ }^{\circledR}$ only, and Vision ${ }^{\circledR}$-only treatments), and considering only the unreleased plots, white spruce survival rates after 13 growing seasons decreased to an average of $22 \%$ at Oates and $18 \%$ at Oswald, declining by $12 \%$ and $14 \%$, respectively, from fifthyear rates. In this trial, the herbicide treatments did not substitute effectively for mechanical site preparation. Certainly, white spruce can be successfully established on competitive boreal mixedwood sites using only the herbicide tool (Sutton 1986, 1995; Harper et al. 1997; Boateng et al. 2000), but there is no obvious reason why Velpar ${ }^{\circledR}$ has given such poor results at Oates and Oswald. The organic matter content of the soil was low, but perhaps dosages were insufficient. Considering initially only the original treatments, and leaving aside the Vision ${ }^{\circledR}$ treatments because of the related uncertainties, Velpar ${ }^{\circledR}$ faced a big task against well-established competition on fertile sites. To obtain survival and a positive growth response from young outplants, sufficient herbicide is needed to effect a slow but steady and sufficient amelioration (Sutton and Edmonds 1996).

\section{Summary and Conclusions}

The experiments at Oates and Oswald, while admittedly flawed, are nevertheless useful in detailing some techniques that have been highly successful for establishing white spruce on sites initially occupied by dense, mainly woody, competition. Perhaps of equal value, is the attention this account draws to pitfalls to be avoided in future trials of this kind. The involvement of the operational forest manager in researching techniques to further the objectives of management is very desirable and has many benefits, and the need of forest managers on occasion to respond to operational exigencies rather than research desiderata is likely to become less of a problem the clearer the consequences become.

There is no doubt that blading site preparation at Oates and Oswald has been very successful in establishing white spruce. Contributing and perhaps essential to this success are the fertile nature of the soil, reasonably good drainage, which precluded flooding of planting microsites, and the nurse effect provided by residual vegetation bordering the treated strips.
Trenching was less successful than blading, presumably because of less complete control of competition, but it was still moderately successful, especially at Oates. At Oswald, while still significantly better than non-mechanical site preparation, trenching gave significantly poorer results than did blading. The greater difference between the two mechanical site preparation treatments at Oswald than at Oates is not attributable to any single obvious cause. The treatments were applied similarly by the same personnel, but the planting stock and weather certainly differed and although the sites were largely similar there were differences.

Herbicides did not perform well in these experiments. To achieve the kind of success that has been obtained elsewhere, rigorous control of timing and rate of application are essential, especially in the initial establishment phase on sites dominated by wellestablished competition.

\section{References}

Boateng, J.O., S. Haeussler and L. Bedford. 2000. Boreal plant community diversity ten years after glyphosate treatment. Western J. Appl. For. 15: 15-26.

Harper, G.J., L.J. Herring and W.J. Hays-Byl. 1997. Conifer and vegetation response in the BWBSmw1 12 years after mechanical and herbicide site preparation. B.C. Min. For. Res. Branch, Victoria, B.C., Work. Pap. 29. 32 p.

Minitab 13. 2002. http://www.minitab.com. Minitab Inc., State College, PA..

Sutton, R.F. 1982. Plantation establishment in the boreal forest: planting season extension. Can. Dep. Environ., Can. For. Serv., Sault Ste. Marie, Ont., Inf. Rep. O-X-344. 129 p.

Sutton, R.F. 1986. Hexazinone Gridballs ${ }^{\mathrm{TM}}$ applied with concurrent underplanting of white spruce in boreal mixedwoods: 7-year results. For. Chron. 62: 226-232.

Sutton, R.F. 1992. White spruce (Picea glauca [Moench] Voss): stagnating boreal old-field plantations unresponsive to fertilization and weed control. For. Chron. 68: 249-258.

Sutton, R.F. 1995. Establishing white spruce plantations. Letter, For. Chron. 71(3): 261

Sutton, R.F. and T.P. Weldon. 1995. White spruce establishment in boreal Ontario mixedwood: 5-year results. For. Chron. 71: 633-638.

Sutton, R.F. and R.M. Edmonds. 1996. Methodologies for maintaining the softwood component in boreal mixedwoods. Nat. Resour. Can., Can. For. Serv., Sault Ste. Marie, Ont., NODA/NFP Tech. Rep. TR-41. $9 \mathrm{p}$. 